\title{
Characterization of producers of Ejido San Luis Huexotla and relationship with socioeconomic structure and agricultural production
}

Espinosa-Morales, Juan Carlos ${ }^{1 *}$, Escalona-Maurice, Miguel J. ${ }^{1}$; Ortega-Méndez Claudia Ivon ${ }^{1}$; Fernández-Ordoñez, Yolanda Margarita ${ }^{1}$

${ }^{1}$ Colegio de Postgraduados, Campus Montecillo, Texcoco, Estado de México.

*Corresponding author: espinosa.carlosacolpos.mx

\section{ABSTRACT}

Objective: To characterize the Ejido agricultural producers relating to their environment and socioeconomic structure in Ejido San Luis Huexotla, Texcoco, state of México, Mexico.

Design/Methodology/Approach: This research joined qualitative and quantitative methodologies. Also, a survey was used and applied to Ejido producers (ejidatarios) of Ejido San Luis Huexotla. To obtain the sample size, total universe of 181 ejidatarios was used; and survey was applied to 50 of them, representing $30 \%$ of the population.

Results: The main problems were identified that have changed land uses and ownership in the Ejido. Variables were found, as aging and primary economic activities that are decisive in order to know the current status of the Ejido area; its spatial transformation, and general conditions of Ejido San Luis Huexotla.

Limitations of the study: Although we are referring to an agricultural area with irrigation systems, diverse causes and socioeconomic factors or even external factors have conditioned the agricultural activity of the Ejido system.

Findings/Conclusions: Applying a survey to ejidatarios was decisive to observe the conditions in which the Ejido is being managed; and to assess vulnerability to external events that have transformed the actions at the Ejido; as well as their socioeconomic relationships facing the inevitable de-peasant process (less owners are rural farmers by the day) in current Mexican agricultural lands.

Key words: agricultural producers, Ejido San Luis Huexotla, socio-economic structure.

\section{INTRODUCTION}

The Ejido

has played an important role within Mexican agriculture as foundation for family agricultural production. However, it has had also the main role in significant changes in terms of land tenure, following 1992 reforms to the Article 27 in the Mexican Constitution Act. This reform modified not only the action of the Ejido, but its social practices and current status.

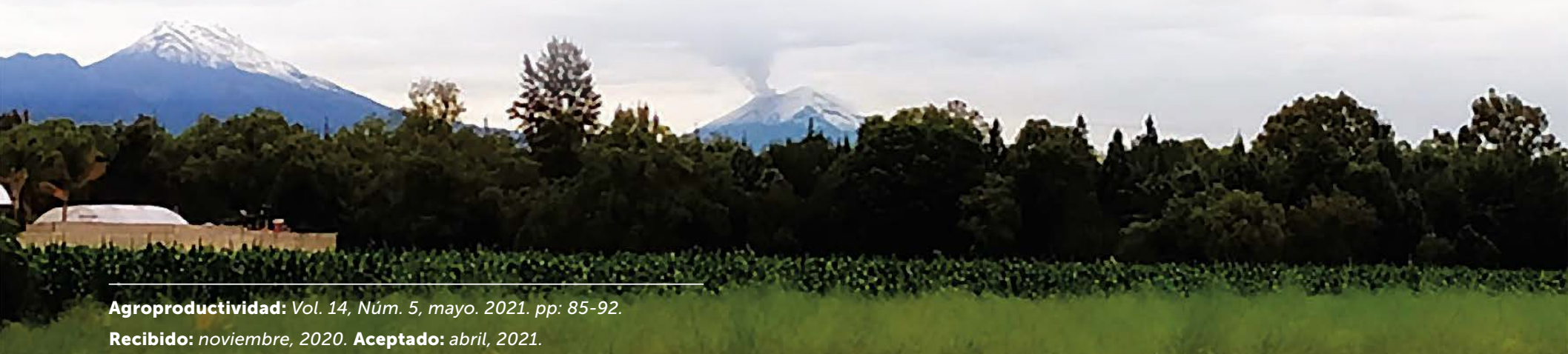

Recibido: noviembre, 2020. Aceptado: abril, 2021 
The Ejido de San Luis Huexotla has a historical precedent of endowment that places it within the extensive process of the agrarian distribution in 1927 (Espinosa, 2017). The Ejido zone which was granted on March 3, 1927 by Presidential decree with a total of 237 ha, of which 108 ha are wetlands; 16 ha are rain fed; and 113 ha are pasture and pond. The environment and its geographical location were crucial for, since 2008, the Federal Government made land purchase of Ejido and communal lands, totaling 1700 hectares in the municipalities of Texcoco and Atenco. These lands belonged to seven ejidos (Santa Isabel Ixtapan, San Luis Huexotla, Hidalgo y Carrizo, San Bernardino, San Cristóbal Nexquipayac, Francisco I. Madero, San Felipe and Santa Cruz). Such a purchase intended to form a rural polygon of soils for the ecological rescue of the whole zone, according to the "Mandatory Book of CONAGUA-07, Lake Texcoco Ecological Program" (CONAGUA, 2012). However, in real terms, that purchase was for what would eventually be the Mexico City New International Airport (NAIM, in Spanish); the first process that drastically changed the dynamics of the Ejido San Luis Huexotla.

In Mexico, land tenure is a fundamental part of the structure of our territories; not only in a political, social, or economic way, but also as a functional structure. Bearing in mind that Ejidos and agrarian communities are the main reference for the geographic occupation of our National territory. And that they occupy 102 million ha (84.5 million, ejidos and 17.4 million, communities), equivalent to $53.4 \%$ of Mexico National surface (Morett, 2017). The 1992 Agrarian Law stated that a Ejido is constituted by the endowment of Ejido lands which, according to their destination are: human settlements; lands of common use parceled out to farmers, managed by a common property association with a decision-making entity - the representative assembly (commissariat) and the control assembly (supervisory council). According to the Agrarian Procurator Office (2009) Ejido is defined as the "population settlement, made up of all the lands, forests, and waters of an endowment, as well as the group of individuals holding those agrarian rights".

This study shows the characterization of ejidatarios regarding their socioeconomic characteristics (age, level of education, social security, possession of land) and their agricultural activity, in order to know their activity status and type of production. All this aiming to have a general scope of the conditions of ejidatarios in Ejido San Luis Huexotla; in addition to identifying those external factors that have modified their actions in the Ejido.

\section{MATERIALS AND METHODS}

This research was carried out in the town of San Luis Huexotla, which is located within the Municipality of Texcoco to the east of the state of Mexico. The municipality is made up of a Municipal District, which is Texcoco de Mora city, divided into 19 territorial units (neighborhoods, colonies, and private subdivisions). And other 60 localities are considered under Texcoco Municipality, that are grouped in 6 zones for their territorial administration management $(\mathrm{H}$. Ayuntamiento, 2016).

San Luis Huexotla (town) has an Ejido zone located on the lake shore of Texcoco, bordering to the north with Col. Nezahualcóyotl; to the south with San Bernardino; to the east with lands of Universidad Autónoma Chapingo (UACH); and to the west with Ejido San Martín. San Luis Huexotla Ejido is divided into the zones: 1st and 2nd tables of San Andrés; El Colorado; and Santa Irene.

Methodology. The study population was selected with the aim of redefining and making accurate the list of ejidatarios, considering the reduction of members due to the sale of the Ejido Huexotla carried out in 2010. After this sale there remained only 181 ejidatarios in Ejido's updated list, although The National Agrarian Registry (in Spanish, RAN) has 237 registered. It was decided to apply the survey to those who still have a plot in the Ejido to obtain data on the type of agriculture they carry out, and to discard those members who sold to CONAGUA in 2010.

To obtain the selection of the sample, a non-probabilistic sampling was considered, because we did not have the official registry list of ejidatarios. The snowball method was used, some ejidatarios were located and they brought in more people to the survey until the sample size of the population was completed. To obtain the appropriate sample size, the universe of 181 ejidatarios was used, and 50 surveys were applied for sampling about $30 \%$ of the total population.

The statistical analysis was carried out in the statistical system SSPS (Statistical Package for the Social Sciences) in addition we used Microsoft Excel to draw the graphs. 


\section{RESULTS AND DISCUSSION}

Results obtained through the survey show that 50 ejidatarios of Ejido Huexotla, provided socioeconomic information that helped us to characterize their personal information. From there, also to know the factors that have determined the land use of their plot possession, and their relationship with it.

Age and Sex. From the analysis of the data obtained we observe that the average age of male ejidatarios is 61 years, and 72 years of women; $88 \%$ are males and only $6 \%$ are females. The number of women is minimum compared to men, and this is logical, considering that for the endowment of Ejido lands in the Mexican agrarian distribution, only men were considered. However, this low percentage of female representation is due to the succession of Ejido rights (Table 1).

The successions because of appeal on the grounds of constitutionality rights (in Spanish, amparo) in agrarian matters are regulated by the Agrarian Law (1992), in Article 17 that mentions the power that the ejidatario has when designating who should succeed him in his rights respect to the plot, and the order of preference in relation to the award of rights upon death. Art. 18 indicates that when the ejidatario did not designate the successor, the agrarian rights are transferred according to the following order: I) Spouse II) Concubine or common-law partner, III) son of ejidatario, IV) one of his ascendants, V) any person who depends economically on him. Article 19 establishes that when there are no successors, the Agrarian Court will sell the rights to the highest bidder among the ejidatarios and avecindados (other people resident in the Ejido).

SAGARPA (2014) mentions that "the majority presence of farmers in old age has implications for the production, handling, and management of natural resources in agriculture". Thus, it is important to mention that the age ranges shown in the following graph depict the condition of field activity at Ejido Huexotla. The aging of the population is a factor regarding production capacity, due to the decrease in physical abilities. The study population shows that $52 \%$ of the producers are over 61 years, this means they are elders; while $44 \%$ are between 40 and 60 years of age (Graph 1).

The decrease in young people in the agricultural sector shows their low participation in the Ejido Huexotla.

\begin{tabular}{c|c|c|c}
\hline \multicolumn{4}{|c|}{ Table 1. Distribution by gender and average age. } \\
Sex & Frequency & $\%$ & Average Age \\
\hline Man & 44 & 88 & 61 \\
\hline Woman & 6 & 12 & 72 \\
\hline Total & 50 & 100 & 66.5 \\
\hline
\end{tabular}

Only 4\% are between 21 and 40 years of age, which represents the abandonment of agriculture, and a possible reorientation of their economic activities.

Education level. According to the results of INEGI (2010), the Municipality of Texcoco has a population of 167,309 people (15 years or older). Of which 5,295 are illiterate; 13,859 people without complete elementary school; and 31,395 without complete secondary (junior high) school. For a total of 50, 549 people lagging behind in education.

From results obtained in the survey, we found that $44 \%$ of ejidatarios studied elementary school, of them, only 10 studied from 2 nd to 5 th grade of elementary school and all the rest finished it. In addition, 24\% studied secondary school. Following these results that show a low academic level in the respondents, illiteracy is identified as a problem, affecting at National level, but especially in the primary production sector. The most lagging behind people regarding education are those who are dedicated to agriculture and other related field activities (Graph 2).

Social security. It shows a comprehensive stability regarding guaranteed health care and medical services, according to IGECEM (2016). Public health system and social security, along with private and social assistance institutions in Texcoco, report a total population of 240 ,

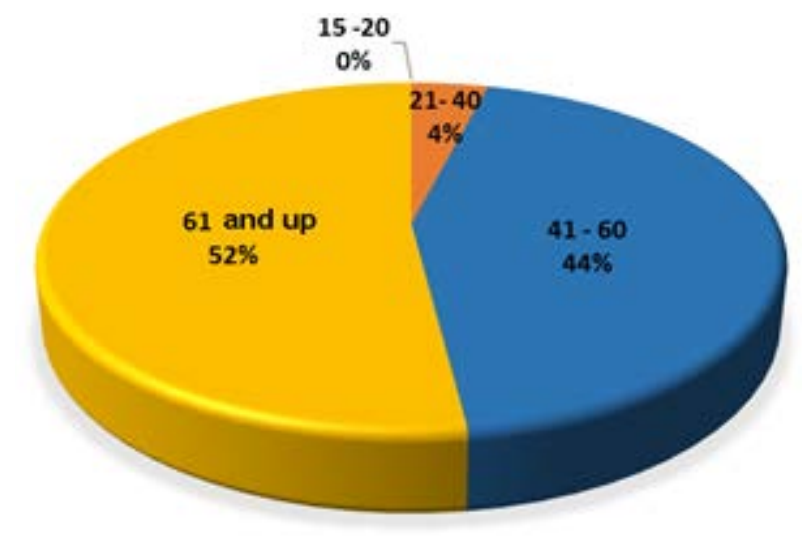

Graph 1. Age of the Huexotla Ejido stakeholders. 


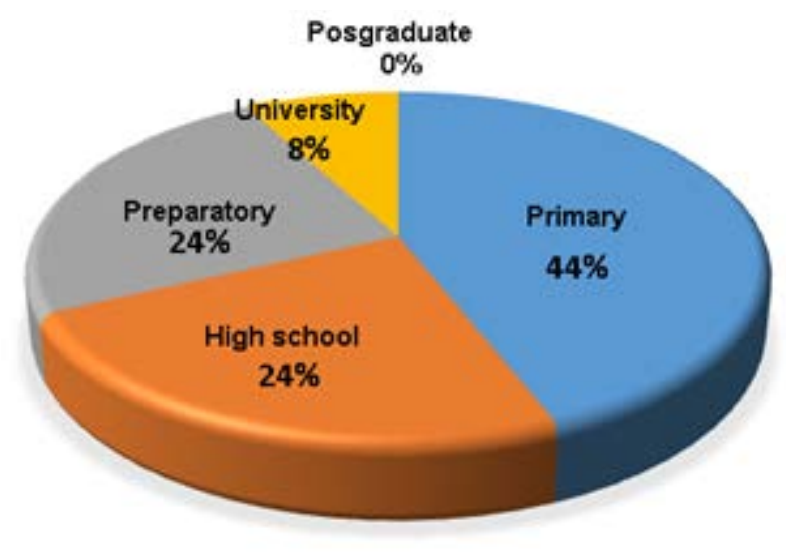

Graph 2. Education level of the respondents.

749 people. Of which 181,785 people are beneficiaries of a social security public institution, and 57,607 do not have any social security scheme.

The medical assistance services are shown in the following table, $62 \%$ people have ISSSTE as their medical service. We should clarify that this service is provided to workers, former workers, family members, and pensioners of the Federal Government and the Federate states. This means that those ejidatarios who have the service, do it because they also work or worked in a government agency. Due to the characteristics of the area, most did in Universidad Autónoma Chapingo (UACh) and Colegio de Postgraduados (COLPOS); while the other $26 \%$ are not affiliated with any medical service, which means that they eventually pay private service (Table 2).

Socio-economic structure. The economic composition is a fundamental piece of information about land owners, their employment, and income from agricultural activities. Because it shows or estimate the economic stability of the ejidatarios' families. In this area of the primary production sector, we can consider that very high risks are run by the abandonment of agricultural

\begin{tabular}{l|c|c}
$\begin{array}{l}\text { Table 2. Social security of ejidatarios in Ejido San } \\
\text { Luis Huexotla. }\end{array}$ & Frequency & $\%$ \\
\hline Medical Services & 31 & 62 \\
\hline ISSSTE & 2 & 4 \\
\hline IMSS & 0 & 0 \\
\hline ISSEMYM & 0 & 0 \\
\hline SSA & 4 & 8 \\
\hline SEGURO POPULAR & 13 & 26 \\
\hline NINGUNO & 50 & 100 \\
\hline Total & &
\end{tabular}

and livestock activities; due to the almost zero obtaining of agricultural products for self-consumption, the scarcity of government support, and the change of land use constantly oriented towards urbanization, that put agriculture at an exponential rate risk. Therefore, it is necessary to know the current condition of Ejido Huexotla.

The economic inputs in the agricultural sector of the region may frame the possibility of continuing to carry out these activities or abandoning it due to the aforementioned factors. It is necessary to indicate that the challenges that the municipal governments must face should be aimed at improving public policies to activate local production; and to stop urbanistic growth that continues to be a prevailing risk factor in spaces originally used for agriculture.

San Luis Huexotla ejidatarios have plots of approximately $1 \mathrm{ha}$, in some cases it varies because they have between $9000 \mathrm{~m}^{2}$ and $10,000 \mathrm{~m}^{2}$, although the majority possess 1 ha of the Ejido land per ejidatario.

Economic income from other activities. It is important to know those economic activities that are not agricultural because those are for some people, sources of main income; henceforth, the dependence degree of agricultural production to them. In this section we get to know this type of additional activities.

In Ejido Huexotla, most ejidatarios alternate their agricultural works with other economic activities that generate the main economic support of their family. It is worth mentioning that the economic income from agriculture is not enough to cover their expenses. Hence the need to have an extra source of income intending to guarantee their financial security (Table 3).

\begin{tabular}{l|c|c}
\multicolumn{2}{c}{ Table 3. Other economic activities of ejidatarios. } \\
\hline Economic activity & Frequency & $\%$ \\
\hline Government employee & 12 & 24 \\
\hline Retired & 20 & 40 \\
\hline Private company employee & 0 & 0 \\
\hline Technical professional & 2 & 4 \\
\hline Businessman & 5 & 10 \\
\hline Laborer & 6 & 12 \\
\hline Tailor & 0 & 0 \\
\hline Other & 5 & 10 \\
\hline Sum & 50 & 100 \\
\hline
\end{tabular}


The economic support of families is a priority in the whole of society, it is part of the responsibility that one must secure family well-being. At the previous table we observe that $40 \%$ of those surveyed are retired people from some government agency. This means that at present they receive a pension for their years of service, while $24 \%$ work in a government institution, and they report economic security, in addition to some day they will be pensioners. We should clarify that 10\% who answered "Another type of activity" are women who got the retirement rights by their deceased husband. Other $4 \%$ have a professional degree and they can get salary for their services. If we add these items, they mean that $78 \%$ of the total interviewees reported to have economic stability (Graph 3).

In general, people who mentioned working or being retired by a government agency have the possibility of guaranteeing economic stability.

The role that these institutions play in the area is fundamental for economic and academic development, not only for the Municipality of Texcoco but also on the National level. Regarding academic sector UACH is a public institution that provides education from Senior High School level, College and Postgraduate degrees. It is dedicated to teaching and research in agronomic and environmental sciences. On the other hand, COLPOS provides Postgraduate education, conducting international research, and providing services and technical assistance in agriculture, and forestry. Both institutions have a large staff of students, which means that the localities around them demand spaces for housing and services, which generates additional economic incomes in the area.

Also, these institutions as employment source generated a local economic dynamic, by providing administrative workspaces, mainly occupied by people of the municipality. The search for new spaces to access a stable economy was the main reason for people to apply to these institutions. There is this guarantee by being government institutions that provide job security, services, benefits that effectively privilege their members. But, on the other hand, this was also the main

\begin{tabular}{|c|c|c|}
\hline Way of acquiring & Frequency & $\%$ \\
\hline Purchase & 6 & 12 \\
\hline Inheritance & 36 & 72 \\
\hline Irregular Possession & 2 & 4 \\
\hline Agrarian cast & 1 & 2 \\
\hline Other & 5 & 10 \\
\hline Total & 50 & 100 \\
\hline
\end{tabular}

Public services in the ejido. One characteristic that should be mentioned is that the Ejido has water wells for irrigation (Santa Irene, San Andrés, Gama). The latter was sold when the purchase was made by CONAGUA in 2010; they also have the use of wastewater since 1975 from the Chapingo river. This court 
sentence was pronounced in the Agrarian Trial number 707/92, relative to the provision of water, promoted by peasants from the town of San Luis Huexotla. Such a request was made since 1979 and granted with an endowment of 414,720 $\mathrm{m}^{3}$ (four hundred fourteen thousand seven hundred and twenty cubic meters) of water, and waterflow of $20 \mathrm{~L} / \mathrm{s}$ during the 8 months of seasonal drought (DOF, 1994).

There is little coverage of public services regarding the Ejido zone, in the following table we see what percentage of services the ejidal properties have. For example, 98\% of the Ejido plots do not have piped water service; thus, the dwellings settled in these spaces have to buy tap water volumes (in water tanker trucks) for domestic use (Table 5).

Natural state of the plots. The type of agriculture carried out by the ejidatarios is a traditional type. They continue to plant basic products such as corn, and their agricultural exploitation depends on personal needs. Although some prefer not to plant it for different reasons. In the following graph we can see the current state in which the lands of the Ejido are. A $58 \%$ of the plots are producing, while $28 \%$ the ejidatarios prefer to rent their land. The latter refers to owners who prefer to obtain a secure profit annually. The price of the annual rent varies according to what is agreed among those involved; from 3,000 to 5,000 thousand pesos (Graph 4).

Type of crops. The main agricultural products that are sown in the Ejido are maize grain with 45\%, and oats with $30 \%$. One of the respondents mentioned planting asparagus; this product is one of the least considered in the Ejido, but with great potential. Although the market is scarce, the economic retribution is higher compared to the basic products planted in the area. It is worth mentioning that this product demands intense care, but the climatic conditions favor its production (Figure 1).

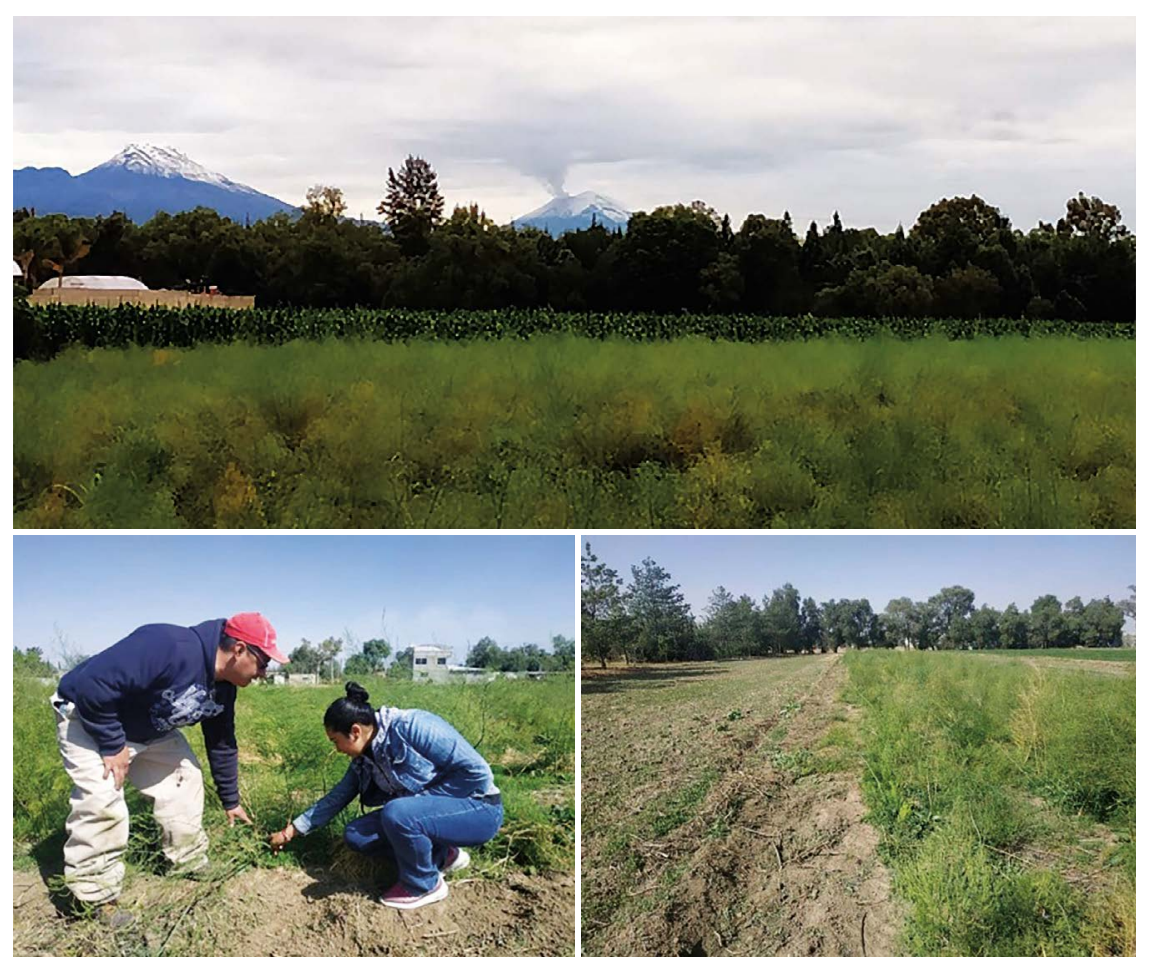

Figure 1. The Asparagus plot. 


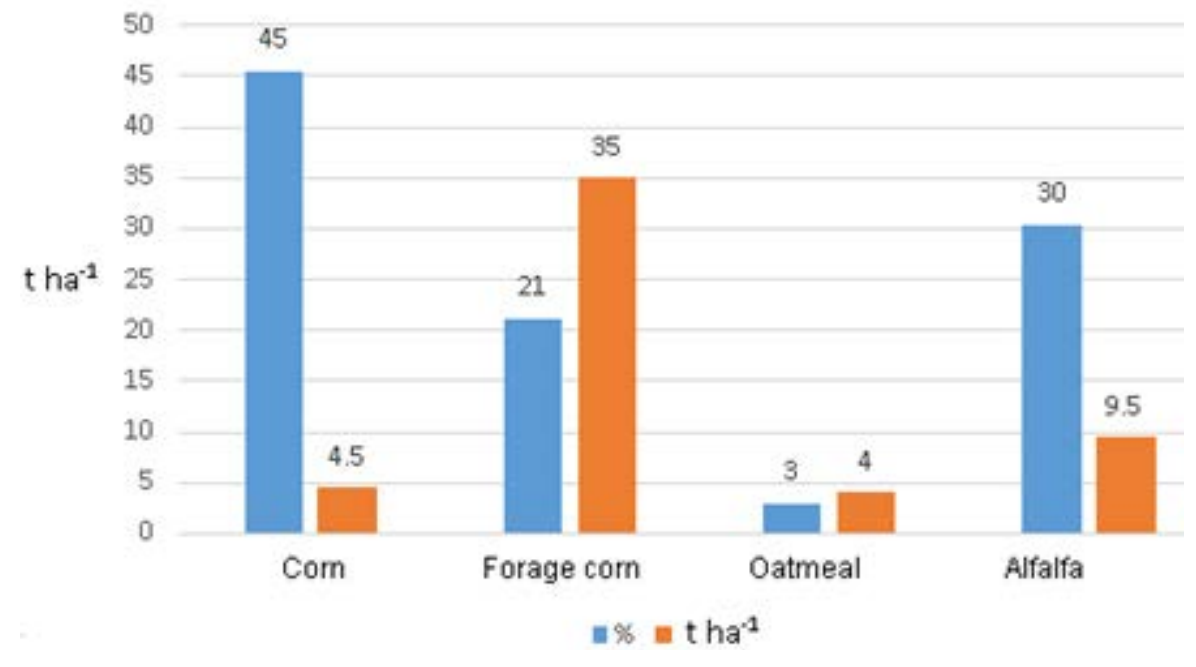

activities in this area. There remains as in alert, the possibility of drastic changes in land use in this area; because surveyed ejidatarios mentioned their willingness to sell if there is a customer with possibility of purchasing. Although they are surrounded by the main agricultural researchers at Mexico's National level, such as UACH, COLPOS and INIFAP, ejidatarios do not approach to them to request information, nor advice to increase their yields and improve production.

Although it is true that agricultural mentioned using it for self-consumption. That is, family food and their animals. Whereas 8 respondents sow maize with the goal of selling their entire production.

Government Supports. Governmental Funds supporting farms is an important factor for the ejidatarios. However only 12 people of the respondents mentioned having any type of support; 8 of them receive the PROCAMPO (Programa de Apoyos Directos para el Campo or support funds directly to the farm) for the amount of $\$ 1,300$ MXN pesos (65 USD) from SAGARPA since 1993. This socalled support is a mechanism for transferring resources to compensate domestic producers by those subsidies that their foreign competitors receive. As replacing the scheme of guaranteed prices for grains and oilseeds (SAGARPA, 2012) (Table 6).

\section{CONCLUSIONS}

The first territorial change that the San Luis Huexotla ejido suffered was the sale of 37.81 ha of the original (53.43 ha) common use area in the Ejido surface. Lands that were sold to CONAGUA in 2010. This meant that 56 ejidatarios sold their plots, leaving the Ejido reduced to a total area of 146 ha. The sale had direct effects on the agricultural production which the irrigated agriculture area used to produce; also, the disappearance of the common use lands at the Ejido.

On the contrary, parceled land price increased because of capital gain, in relation to agricultural land price, due to demand of surface for the constructions associated with the establishment of the NAICM (Mexico City New International Airport). All this presents a risk to the entire ejidal zone and generated the decrease of agricultural land in the Ejido zone up to 2016 decreased due to the sale to CONAGUA, we also observed that there is an agricultural decrease in the whole area. Results show disinterest in carrying out agricultural activities. We found just $58 \%$ of the plots are producing, while the remaining $42 \%$ of people do not work lands directly. Therefore, this leads to think that agriculture for the ejidatarios does not represent a profitable economic activity; fact that is expressed through a lot of lands in rest, without agricultural activity. Associated with this trend, the survey found that $74 \%$ of the ejidatarios work or have worked in a government agency like COLPOS or UACH. Most frequently, this shows that, associated with the aforementioned decrement problems on the agricultural production, the abandonment process is also related to obtaining a stable source of income. All this leads to leaving agricultural activities as second and even third economic option.

On the other hand, the agricultural structure has also generated a change in land uses in the Ejido zone. Thus leading to modifying production processes; causing rent of their lands, abandoning them or even selling in some cases. Ejidatarios informed that $58 \%$ of them cultivate

\begin{tabular}{l|c|c}
\multicolumn{3}{c}{ Table 6. Type of Government Support Funds for Farming. } \\
\hline \multicolumn{1}{c|}{ Program } & $\begin{array}{c}\text { Number of } \\
\text { supports }\end{array}$ & Type of support \\
\hline Procampo & 8 & 1300 pesos \\
\hline Alliance for the field & 2 & Fertilizer \\
\hline Livestock Program & 1 & 3750 per 10 head of cattle \\
\hline $\begin{array}{l}\text { Strategic Food } \\
\text { Security Project } \\
\text { (PESA) }\end{array}$ & 1 & Technical Advisory \\
\hline
\end{tabular}


their lands; $28 \%$ rent them; $8 \%$ leave them on rest; and $4 \%$ give them on loan. Of the percentage that actually cultivate lands, those products obtained are destined, 55\% for self-consumption and $45 \%$ for sale.

Finally, a factor that has also influenced the low production of the agricultural area has to do with the elder age of the ejidatarios. Aging is one of the main factors limiting agricultural production, regarding primary human capital (FAO, 2014; SAGARPA, 2014).

\section{REFERENCES}

CONAGUA (2012). Comisión Nacional del Agua, Libro Blanco Conagua-07 "Programa Ecológico Lago de Texcoco". Gobierno Federal.

Diario Oficial de la Federación (1994). Dotación de agua, Sentencia pronunciada en el juicio agrario número $707 / 92$.

Espinosa Morales J.C. 2017. Cambio de ocupación del suelo en la localidad de San Luis Huexotla Texcoco Estado de México en el período 1996-2016: Tesis de Maestría en Ciencias. Colegio de Postgraduados, México.

IGESEM (2016) Instituto de información e Investigación geográfica, estadística y catastral del Estado de México. "Estadística básica municipal"

INEGI, (2010). Censos Generales de Población y Vivienda.

FAO (2014). Organización de las Naciones Unidas para la Alimentación y la Agricultura. "Estudio sobre el envejecimiento de la población rural en México

H. Ayuntamiento Texcoco (2016). Bando de Gobierno del Municipio de Texcoco.

Ley Agraria (1992). Cámara de Diputados del Congreso de la Unión. Últimas Reformas DOF25-06-2018

Morett-Sánchez, J. Carlos, \& Cosío-Ruiz, Celsa. (2017). Panorama de los ejidos y comunidades agrarias en México. Agricultura, sociedad y desarrollo, 14(1), 125-152. Recuperado en 13 de octubre de 2020, de http://www.scielo.org.mx/scielo.php?script=sci_arttext\&pid=\$1870-54722017000100125\&lng=es\&tlng $=$ es.

Procuraduría Agraria (2009), Glosario de términos jurídico-agrarios,

Ruiz Alarcón, A. (2014). La organización ejidal en el desarrollo rural de México. Estudios Agrarios. 2015, 59, 181-204 204

SAGARPA (2012). Programa de Apoyos Directos al Campo (PROCAMPO). Reglas de operación.

SAGARPA, (2014). Estudio sobre el envejecimiento de la población rural en México.

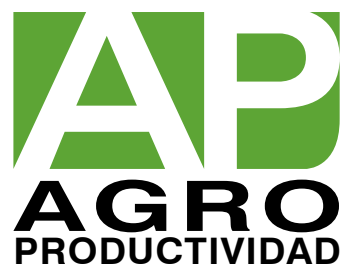

